\title{
AUTORIDADE PARENTAL E PRIVACIDADE DO FILHO MENOR: O DESAFIO DE CUIDAR PARA EMANCIPAR
}

PARENTAL AUTHORITY AND THE PRIVACY OF THE MINOR CHILD: THE CHALLENGE OF PROVIDING CARE TO EMANCIPATE

AUTORIDAD PARENTAL E INTIMIDAD DEL HIJO MENOR DE EDAD: EL DESAFÍO DE CUIDAR PARA EMANCIPAR

"There are only two lasting bequests we can hope to give our children. One of these is roots; the other, wings." - H. Carter

Joyceane Bezerra de Menezes1

Maria Celina Bodin de Moraes2

1 Doutora em Direito pela Universidade Federal de Pernambuco UFPE. Professora Titular do Programa de Pós-Graduação em Direito da Universidade de Fortaleza PPGD-UNIFOR, em estágio de pós-doutorado na Universidade do Estado do Rio de Janeiro UERJ.

2 Professora Titular de Direito Civil da UERJ e Professora Associada do Departamento de Direito da PUC-Rio. Doutora em Direito Civil pela Universidade de Camerino, Itália. 
Resumo: Este artigo analisa os novos contornos do poder familiar que se estabelece no âmbito da família democrática. Nessa forma múltipla de organização familiar, cônjuges, conviventes, pais e filhos estabelecem relações de coordenação orientadas pela solidariedade. Os filhos são reconhecidos como sujeitos de direitos e protagonizam, sob a orientação dos pais, a construção de sua personalidade. Nesse aspecto, são titulares de direitos fundamentais cujo exercício não pode ser efetivado pelo mecanismo de substituição de vontade, tal como se verificava na incidência do antigo pátrio poder. Os filhos têm capacidade de exercício de seus direitos de liberdade e privacidade mesmo em face dos pais, porque $o$ poder destes, no cuidar dos filhos, se tornou limitado pela função instrumental da promoção da personalidade daqueles.

Palavras-chave: Direitos fundamentais. Vulnerabilidade. Menoridade. Poder familiar.

Abstract: This paper analyses the new forms of family power that are established in the democratic family. In this multiple form of family organization, spouses, those sharing the home, parents and children establish relationships of coordination based on mutual solidarity. Children are recognized as subjects with rights, and under their parent's guidance, develop their personalities. They are, therefore, holders of fundamental rights that cannot be exercised through the mechanism of substitution of free will, as is seen in the incidence of the old patriarchal power. Children have the capacity to exercise their rights to freedom and privacy, even if it is against the parents, because the power of the latter, in the care of their children, is limited to the instrumental function of promoting their children's development.

Keywords: Fundamental Rights. Vulnerability. Minors. Children. Parental Power.

Resumen: Este artículo analiza los nuevos contornos del poder familiar que se establecen en el ámbito de la familia democrática. En esa forma múltiple de organización familiar, cónyuges, convivientes, padres e hijos establecen relaciones de coordinación orien- 
tadas por la solidaridad. Los hijos son reconocidos como sujetos de derechos y protagonizan, bajo la orientación de los padres, la construcción de su personalidad. En ese aspecto, son titulares de derechos fundamentales cuyo ejercicio no puede llevarse a cabo por el mecanismo de sustitución de la voluntad, tal como se verificaba en la incidencia del antiguo patrio poder. Los hijos tienen la capacidad de ejercitar sus derechos de libertad e intimidad incluso frente a los padres, porque el poder de ellos - no cuidar a los hijos -, quedó limitado por la función instrumental de la promoción de la personalidad de los mismos.

Palabras clave: Derechos fundamentales. Vulnerabilidad. Minoridad. Poder familiar. 


\section{INTRODUÇÃO}

$P$ or ocasião da abertura da Copa do Mundo de 2014, na cidade de São Paulo, uma equipe de reportagem do Jornal Globonews captou uma discussão entre pai e filho que serve bem para ilustrar o atual conflito entre a liberdade do menor e a autoridade parental. ${ }^{3} \mathrm{O}$ jovem, com dezesseis anos, participava de um protesto, visando bloquear o acesso dos torcedores ao Estádio e foi reconhecido pela mãe pela televisão. Temendo os riscos para a integridade do filho, os pais seguiram para o local e o pai puxou e empurrou o filho, buscando tirá-lo dali e levá-lo para casa. Embora a intervenção paterna tenha se iniciado de forma autoritária, foi sucedida por um intenso e nervoso diálogo que acabou convencendo, "pelo cansaço", o filho a seguir com seu pai. ${ }^{4}$

O embate público propagou o grau de dificuldade que hoje enfrentam os pais para educar as crianças e os adolescentes das gerações atuais. ${ }^{5}$ Será possível cumprir adequadamente a tarefa parental de cuidar dos filhos, havendo que lhes respeitar a liberdade e a privacidade? A resposta a esta indagação encontrase entrelaçada ao aspecto funcional do poder familiar, cuja finalidade precípua passou a ser a promoção do desenvolvimento da personalidade dos filhos, respeitando sua dignidade pessoal.

Nas relações pessoais ou não patrimoniais, há a necessidade de superar a rígida contraposição entre maioridade e minoridade, capacidade e incapacidade, expressões de uma alternativa jurídica formal que simplesmente não corresponde à realidade. ${ }^{6}$ A capacidade de entender e de quereré expressão da gradual evolução

3 Vídeo disponível em: <http://veja.abril.com.br/noticia/brasil/consegui-convence-lo-pelacanseira-diz-pai-de-black-bloc>. Acesso em: 15.10.2014.

4 A disputa familiar foi flagrada pela imprensa mundial e o vídeo tornou-se o assunto do dia nas redes sociais. Em casa, o pai explicou que não proíbe a manifestação do filho em protestos por causas legítimas, mas que não admite a sua participação no movimento Black Bloc, com o rosto coberto "como se fosse um bandido", por temer pelos riscos à sua segurança e à sua integridade física. Indagado sobre a experiência, o pai afirmou: "meu filho perdeu o direito de protestar quando cobriu o rosto; cumpri meu papel de pai e faria de novo"; já o filho, sentado ao lado, disse apenas: "foi horrível". Disponível em: http:// veja.abril.com.br/noticia/brasil/consegui -convence-lo-pela-canseira-diz-pai-de-black-bloc. Acesso em: 15.06.2014.

5 Ditas "geração y" e "geração milênio".

6 PERLINGIERI, 1972, p. 137. 
da pessoa humana, titular de direitos fundamentais por definição intransferíveis, a qual deve ser posta em condições de atuá-los, concomitantemente à sua idoneidade, devendo ser afastados os obstáculos ao seu exercício pessoal. ${ }^{7}$

Se a função do poder familiar passou a ser educar para contribuir para o bom desenvolvimento da personalidade da criança, não há como fazê-lo somente mediante o cerceamento da liberdade, sendo preciso também, e principalmente, promovê-la e respeitá-la. ${ }^{8}$ A despeito da multimilenar limitação à capacidade de exercício do menor, parece hoje imprescindível reconhecer-lhe a capacidade de agir que já houver alcançado no seu processo de amadurecimento e emancipação, conferindo-se a ele as escolhas existenciais, personalíssimas, para as quais demonstra a competência necessária. O desafio está em identificar a justa medida entre o cuidar e o emancipar.

\section{AS RECENTES ORIGENS DOS DIREITOS FUNDAMENTAIS DA} CRIANÇA E DO ADOLESCENTE

Dentre os documentos sobre os direitos humanos, a necessidade de proteção especial à infância foi mencionada pela primeira vez em 1924, na Declaração de Genebra, embora desde 1919 a incipiente "Sociedade das Nações" houvesse já criado o Comitê de Proteção da Infância. Bem mais tarde, a UNICEF promulgou a Declaração Universal dos Direitos da Criança (1959), à qual se seguiram diversos Pactos Internacionais de Direitos (1966, 1968, 1972), bem como outros estatutos e instrumentos internacionais e multilaterais $(1969)^{9}$ voltados para a promoção do bem-estar da criança, reiterando a importância e a necessidade de uma tutela especial e ampla, inclusive jurídica, tanto antes como depois de seu nascimento.

Já na Declaração Universal de 1959 são estabelecidos os marcos para a inflexão em relação à da doutrina da proteção integral, em substituição à doutrina então vigente da proteção dita "menorista", voltada exclusivamente para os menores

7 PERLINGIERI, 2008, p. 1003.

8 VILLELA, 1980.

9 Nas Américas, o Pacto de São José da Costa Rica, celebrado em 1969, estabeleceu, entre tantos direitos, que "toda criança tem direito às medidas de proteção que sua condição de menor requer por parte da família, da sociedade e do Estado" (art. 19). 
em situação de risco. Embora o texto não fosse de cumprimento obrigatório, nele é possível reconhecer o início do fim do patriarcalismo. ${ }^{10}$

A Declaração conta com apenas dez princípios e os mais relevantes são o Princípio II, intitulado "Direito à especial proteção para o seu desenvolvimento físico, mental e social", estipula que "a criança gozará de proteção especial e disporá de oportunidade e serviços a serem estabelecidos em lei e por outros meios, de modo que possa desenvolver-se física, mental, moral, espiritual e socialmente de forma saudável e normal, assim como em condições de liberdade e dignidade" e o Princípio X, denominado "Direito a crescer dentro de um espírito de solidariedade, compreensão, amizade e justiça entre os povos", o qual prevê que "a criança deve ser protegida contra as práticas que possam fomentar a discriminação racial, religiosa, ou de qualquer outra índole, devendo ser educada dentro de um espírito de compreensão, tolerância, amizade entre os povos, paz e fraternidade universais e com plena consciência de que deve consagrar suas energias e aptidões ao serviço de seus semelhantes".

Em 1989, a Assembleia Geral das Nações Unidas adotou a Convenção sobre os Direitos da Criança, ${ }^{11}$ anunciando um conjunto de direitos voltados especificamente para a população infanto-juvenil, consolidando a doutrina da proteção integral, por considerar seu estágio de desenvolvimento e sua condição de vulnerabilidade. A Convenção foi assinada pelos 194 países que compõem a ONU e ratificada por 193 nações: configura-se, portanto, como o instrumento jurídico mais amplamente aceito na história da humanidade. ${ }^{12}$

10 Vale relembrar a sua origem: "A família romana clássica é de tipo patriarcal: o pai de família (paterfamilias), enquanto vive, é o chefe de todos os descendentes (liberi). Só ele é sui iuris, por oposição aos seus descendentes que apenas são alieni iuris. Goza, relativamente a estes, de um poder mais ou menos ilimitado (...) É nas suas mãos que se concentram todos os direitos e todos os bens da família" (GILLISEN, 1995).

11 O Art. $1^{0}$ da Convenção estipula o significado do termo "criança": "Para efeitos da presente convenção considera-se como criança todo ser humano com menos de 18 anos de idade, a não ser que, em conformidade com a lei aplicável à criança, a maioridade seja alcançada antes".

12 Disponível em: http://www.unicef.org/brazil/pt/resources_10120.htm. Acesso em: 20.08.2014. Até novembro de 2013, os Estados Unidos, a Somália e o Sudão do Sul não haviam ratificado a convenção. Atualmente, só os Estados Unidos não a ratificaram. Diz-se que um dos principais motivos pelo qual os EUA assinaram a Convenção, mas não a ratificaram, decorre do teor do art. 370, alínea a, referente à proibição da cominação de pena de morte e de prisão perpétua a menores de 18 anos, incompatível com o direito de diversos estados norte-americanos. 
No Brasil, sua ratificação se fez pelo Decreto n 9.710/1990, mas o país já incorporara a doutrina da proteção integral do menor na Constituição de 1988 e reafirmou-a no Estatuto da Criança e do Adolescente (Lei n 8.069/1990). Sob a fundamentação de tais normas, crianças e adolescentes passaram a ser considerados como sujeitos de direitos humanos e fundamentais, destinatários de especial proteção, inclusive na esfera intrafamiliar.

Pode parecer estranho que a criança e o adolescente gozem de respeito, privacidade e liberdade, dentre outros direitos, diante daqueles a quem cabe criá-los, assisti-los e educá-los, garantindo-lhes proteção e segurança (art. 229, CF e art.1.634, CC). Na realidade, ecoa ainda entre nós a ideia de que os filhos são sujeitos passivos na relação com seus pais, figurando mais como "objetos de direito" da autoridade parental.

E todavia, a Constituição de 1988, em seu art. 227', caput, já preconizava a "absoluta prioridade" dos direitos da criança e do adolescente à vida, à saúde, à alimentação, à educação, ao lazer, à profissionalização, à cultura, à dignidade, ao respeito, à liberdade e à convivência familiar e comunitária.

Da mesma forma, o legislador do Estatuto da Criança e do Adolescente Ihes assegurou expressamente, no art. 15, o direito à liberdade, ao respeito e à dignidade, como pessoas em processo de desenvolvimento e como sujeitos de direitos civis, humanos e sociais garantidos na Constituição e nas leis. Foi além, afirmando, no art. 16, que a tutela da liberdade consiste no direito de locomoção, de opinião e expressão, de crença e culto, de brincar e divertir-se, bem como de participar da vida familiar, da vida comunitária e da vida política, sendo-Ihes deferida a possibilidade de buscar refúgio, auxílio e orientação. ${ }^{13}$ Tal direito implica a inviolabilidade de sua integridade física e psíquica, abrangendo a preservação de sua imagem, identidade, autonomia, valores, ideias e crenças, dos espaços de autonomia e de seus objetos pessoais (art.17).

Cumpre reconhecer, portanto, que as crianças e os adolescentes não são adultos mais jovens, mas são "seres diferentes", que, embora estejam em fase de crescimento e de formação, são portadores de projetos de vida próprios, 13 Sobre o lado negro desta liberdade, v. MORAES, 2012, p. 1. 
devendo-se "buscar justamente sua promoção integral, de modo a apoiar o desenvolvimento adequado destes projetos de existência". ${ }^{14}$

\section{RELAÇÕES DE PODER E EXERCÍCIOS DE LIBERDADE NA FAMÍLIA CONTEMPORÂNEA}

A tendência da família ocidental contemporânea, já por muitos ressaltada, é tornar-se um grupo cada vez mais desorganizado, pouco hierarquizado e independente de relações consanguíneas, baseado em laços afetivos e em valores compartilhados. ${ }^{15}$ Com efeito, desde as últimas décadas do século $\mathrm{XX}$, o ambiente familiar voltou a tornar-se desejável porque um de seus principais atrativos passou a ser o respeito por cada um de seus componentes, tanto dos maridos com relação às mulheres quanto dos pais em relação aos filhos, alterando as relações de excessiva autoridade antes existentes. ${ }^{16}$ Essa variante permitiu a ampliação, pouco a pouco, dos espaços de autonomia, de crescimento individual e de autoafirmação de cada membro no âmbito do grupo. ${ }^{17}$

Tal processo foi acompanhado pela doutrina e pela jurisprudência brasileiras que cumpriram, inegavelmente, nas últimas décadas importante papel promocional na construção das novas entidades familiares, plurais justamente porque deixadas à livre escolha de seus membros. Se fosse possível reuni-las em um único gênero, este novo modelo poderia ser denominado "democrático"18 correspondente, em termos históricos, à significativa novidade da inserção, no ambiente familiar, de direitos fundamentais como a igualdade e a liberdade. ${ }^{19}$

14 LEWICKI, 2000, p. 14.

15 ROUDINESCO, 2003.

16 SINGLY, 1996.

17 Como observa Singly (2000), os indivíduos das sociedades contemporâneas ocidentais não podem ser comparados aos das gerações precedentes, dado o imperativo atual de tornarem-se indivíduos originais e únicos. Em consequência, a família modificou-se para produzir tais indivíduos, podendo-se notar dois momentos distintos ao longo do séc. XX. "Até a década de 1960, a comunidade familiar ainda permanecia como uma unidade totalizadora, a serviço da qual agiam seus membros; a partir de então, caracteriza-se por uma nova concepção de indivíduos em relação a seu grupo de pertencimento, na medida em que eles se tornam, como membros, mais importantes do que o conjunto familiar: o indivíduo único, cuja "verdadeira natureza" deve ser respeitada e incentivada".

18 GIDDENS, 1993, p. 205.

19 A democratização, no contexto da família, implica igualdade, respeito mútuo, autonomia, 
O direito civil contemporâneo confia o poder familiar a ambos os genitores, que assumem, igualitariamente, um feixe de posições jurídicas (dever, poder, direito, faculdade, interesse) voltado para a complexa finalidade de educar, criar, assistir, representar o filho e gerir seu patrimônio, a fim de contribuir para o melhor desenvolvimento de sua própria personalidade, perspectiva completamente oposta à antiga configuração do poder familiar como podersujeição, o chamado pátrio poder, no qual o pai era visto como o "proprietário" do destino dos filhos.

Aos pais cabe, portanto, a função primordial de buscar promover as potencialidades criativas do filho, de modo a sobrelevar o interesse do menor que se identifica com a obtenção de uma autonomia pessoal (emancipação) e se concretiza na possibilidade de expressar escolhas e propostas alternativas em relação aos mais diversos setores, dos interesses culturais àqueles políticos e afetivos, salvaguardados sua integridade psicofísica e o crescimento de sua personalidade. ${ }^{20}$

Nesse processo, devem balizar o exercício da autoridade parental no melhor interesse do menor e não mais no eventual interesse da família, como instituição, ou dos próprios pais num esforço de manutenção da conjugalidade a qualquer custo.

Os interesses pessoais da criança e do adolescente devem ser levados em consideração, assim como a sua capacidade de agir, na medida de sua maturidade e discernimento, especialmente no que tange às decisões existenciais. $\mathrm{Na}$ qualidade de sujeitos de direitos fundamentais, não parece razoável que possam ser privados do seu exercício, quando apresentarem o necessário discernimento. ${ }^{21}$ A autoridade parental deve, portanto, buscar respeitar as inclinações e aspirações naturais do filho, bem como estimular o exercício de uma autonomia responsável. Ainda que devam, durante o processo educativo e em nome do melhor interesse do filho, restringir a sua liberdade ou, ainda mais eventualmente, sua privacidade, os pais precisam estar aptos a manejar sua autoridade de forma negociada. ${ }^{22}$

tomada de decisão por meio da comunicação, resguardo da violência e da integração social (GIDDENS, 1993, p. 205).

20 PERLINGIERI, 2007, p. 259.

21 PERLINGIERI, 2007, p. 261.

22 A Lei no 13.010, de 2014 estabeleceu o direito da criança e do adolescente a serem educados e cuidados sem o uso de castigos físicos e de tratamento cruel ou degradante. 
Com efeito, cada vez mais raramente se poderá chegar, no caso concreto, ao conteúdo de qual seja o melhor interesse de um adolescente sem investigar tanto suas necessidades como sua vontade. ${ }^{23}$ A própria Convenção sobre os Direitos da Criança determina ter ela o direito de ser ouvida e de participar, na medida de sua capacidade e discernimento, das decisões concernentes aos seus interesses, como um sujeito de direito e não como objeto de proteção. ${ }^{24}$

Tampouco se alcançará o melhor interesse da criança sem se avaliarem nas atitudes parentais, os aspectos pertinentes ao cuidado e ao afeto, condições indispensáveis à formação da personalidade de qualquer ser humano. No sentido amplo, cuidado implica "garantir às crianças e aos adolescentes condições de desenvolvimento físico e emocional adequado, que lhes permita, inclusive, o sentimento de fazer parte de uma família, em cujo seio possam vivenciar o afeto, a confiança, a cumplicidade, proporcionando-Ihes condições de estabilidade emocional". ${ }^{25}$

Na realidade, porém, as estatísticas que apontam os índices de violência contra crianças e adolescentes no Brasil, especialmente no âmbito familiar, ${ }^{26}$ denunciam uma expressão verdadeiramente patogênica da autoridade parental, quase oposta ao que seria sua expressão ideal. Dados do Sistema de Informação de Agravos de Notificação do Ministério da Saúde registraram no atendimento pelo Sistema Único de Saúde, em 2011, cerca de 40 mil atendimentos a crianças e adolescentes, com ampla prevalência a crianças menores de um ano e do sexo feminino. Tais quantitativos, como foi ressaltado, representam somente a "ponta do iceberg". ${ }^{27}$

23 MARTINS, 2009, p. 87-89. Diversos são os dispositivos nacionais que preveem expressamente a necessidade de oitiva e até mesmo consentimento do maior de 12 anos: assim, por exemplo, sua adoção, a alteração de seu prenome, entre outros.

24 Convenção sobre os Direitos da Criança e do Adolescente: "Artigo 12. 1. Os Estados Partes assegurarão à criança que estiver capacitada a formular seus próprios juízos o direito de expressar suas opiniões livremente sobre todos os assuntos relacionados com a criança, levando-se devidamente em consideração essas opiniões, em função da idade e maturidade da criança. (...)".

25 TUPINAMBÁ, 2008, p. 138.

26 Sobre a violência doméstica conjugal, v. o editorial da civilistica.com - Revista eletrônica de Direito Civil, 2013, escrito por Maria Celina Bodin de Moraes. Disponível em: http://civilistica.com/uma-ideia-louvavel-contra-a-violencia-domestica/. Acesso em: 15.10.2014.

27 Conforme dados registrados pelo Mapa da Violência de 2012, compilados por Julio J. WAISELFISZ, Centro de Estudos Latino-Americanos - CEBELA, Rio de Janeiro. Disponível em: 


\section{UM MÍNIMO DE CONHECIMENTO É NECESSÁRIO PARA O BOM DESEMPENHO DA FUNÇÃO}

Deixando de lado os extremos casos de violência registrados pelas estatísticas ou pelas manchetes dos jornais, ${ }^{28}$ é de se perguntar sobre os corriqueiros casos de violação dos direitos da criança na rotina doméstica, quiçá com alguma tolerância da família e da comunidade. Essas violações aos direitos da criança podem ter as mais diversas explicações: o desamor pelo filho, ou o amor excessivo, a mágoa em relação ao outro genitor, o desequilíbrio emocional mais acentuado do abusador ou a mera inabilidade para conduzir a criação. Não é raro que os pais se vejam perplexos diante de circunstâncias sobre as quais não sabem como reagir. ${ }^{29}$

Em todo caso, esses fatores parecem resultar da compreensão equivocada que se tem sobre o papel da autoridade parental. Conquanto os pais não detenham, evidentemente, o poder de proteger seus filhos de tudo aquilo que possa lhes prejudicar, têm o dever de se manterem atentos, a fim de cumprir o seu papel da melhor maneira possível e de evitarem, pelo menos, causar dano proposital aos seus filhos.

Não raro, porém, pais que foram vítimas de comportamento violento e abusivo de seus genitores tendem a reproduzir a conduta ofensiva ou a incorrer no outro

http://www.mapadaviolencia.org.br/pdf2012/MapaViolencia2012_Criancas_e_Adolescentes. pdf. Acesso em: 20.10.2014.

28 O caso mais recente, do terror doméstico seguido de assassinato de Bernardo Boldrine, 11 anos, expôs ao público os severos riscos que a criança pode sofrer no convívio com os seus familiares, não havendo melhor exemplo da importância e da dificuldade da oitiva da criança que busca refúgio e proteção em face de seus pais. Na reportagem do jornal Folha de São Paulo se lê: "No final do ano passado, Bernardo chegou a ir até o fórum da cidade. 'Já que o pai não dava atenção para ele e que a madrasta não tinha paciência, ele queria uma família nova'. Na época, a promotora chegou a solicitar que a guarda fosse transferida para a avó materna. O pai, porém, culpou o trabalho [era médico] e insistiu em ficar com o filho". Disponível: http://www1.folha.uol.com.br/cotidiano/2014/05/1453670-policia-indicia-tres-suspeitos-por-morte-de-bernardo.shtml. Acesso: em 20.10.2014.

29 Segundo Alain de Botton, quando um casal decide ter filhos, acredita que a parentalidade "seja algo inato e que sua experiência como filho será suficiente para o exercício do novo papel". No entanto, a parentalidade é um desafio repleto de dificuldades, medos e dúvidas. "Em especial, o nascimento do primeiro filho configura-se como um evento determinante na vida adulta e, consequentemente, em seu processo de desenvolvimento; as implicações daí advindas impõem mudanças nos mais diversos níveis, pessoal e social, e demandam respostas imediatas, com frequência completamente desconhecidas pela grande maioria dos pais" (BOTTON, 2011). 
extremo: excessivo rigor ou excessiva tolerância. ${ }^{30}$ Quando vítimas de severidade excessiva, passam a tratar seus filhos com uma tolerância desmedida; se na infância certos aspectos da vida lhes haviam sido ocultados escrupulosamente, agora os expõem aos filhos de modo excessivamente esclarecedor. A paternidade e a maternidade, como se sabe, não operam o milagre de desnudar o indivíduo de suas experiências positivas e negativas; por isso, para melhor cumprir o papel parental, é necessário que o indivíduo consiga organizar as suas próprias emoções, em especial, seus sentimentos ambivalentes. ${ }^{31}$

O exercício do poder familiar requer responsabilidade; portanto, certa maturidade e alguma saúde, razão pela qual os pais também precisam ser assistidos e orientados quando não conseguirem levar a efeito o seu ofício parental. Ainda que o planejamento familiar seja livre decisão da pessoa e/ou do casal, uma vez que Ihes sobrevenham filhos, a responsabilidade por sua criação, é inexorável. Caberá a eles a tarefa de promover o desenvolvimento dos seus filhos, proporcionando-lhes as condições materiais e imateriais necessárias, independentemente das marcas e das cicatrizes que já acumularam ao longo da vida.

Hoje se sabe que a personalidade já está presente na criança, cabendo aos pais incentivar o seu desenvolvimento no decorrer da vida até que cheguem à fase adulta. Neste sentido, afirma-se que a criança possui "uma capacidade progressiva, igual em dignidade ao adulto, sujeito ativo na construção do seu futuro numa relação intersubjetiva com os pais, titular de direitos fundamentais". ${ }^{32}$ Ao longo da vida, o ser humano se constrói e se reconstrói, sendo decisivo o apoio da família, especialmente nos primeiros anos.

A "teoria do apego", desenvolvida por John Bowlby (2006), destaca a importância do afeto de modo a garantir às crianças uma base segura na formação de sua personalidade. Conjugando o amor e o cuidado, os pais edificariam essa base segura

30 JUNG, 2011.

31 Nas conclusões de John Bowlby, "existe uma forte relação causal entre as experiências de um indivíduo com seus pais e sua capacidade posterior para estabelecer vínculos afetivos, e que certas variações comuns dessa capacidade, manifestando-se em problemas conjugais e em dificuldades com os filhos, assim como nos sintomas neuróticos e distúrbios de personalidade, podem ser atribuídas a certas variações comuns no modo como os pais desempenham seus papéis." 2006, p. 179.

MARTINS, 2009, p. 86-87, 
capaz de oferecer à criança o suporte e a confiança quanto à fonte e à disponibilidade de apoio. Isso porque, na feliz síntese de Alain de Botton, parece impossível nos sentirmos importantes para nós mesmos, "suficientemente dignos de conduzir nossa figura absurda pelos labirintos da vida, a não ser que em algum momento nós tenhamos sido privilegiados o suficiente para desenvolver um sentimento de que outra pessoa se importava de forma ilimitada e desmedida conosco". ${ }^{33}$

Para Bowlby, "acumulam-se evidências de que seres humanos de todas as idades são mais felizes e mais capazes de desenvolver melhor seus talentos quando estão seguros de que, por trás deles, existem uma ou mais pessoas que virão em sua ajuda caso surjam dificuldades"34 As crianças que crescem na companhia de pais que proporcionam essas condições apresentam-se mais seguras, autoconfiantes e mais cooperativas com as outras pessoas. ${ }^{35}$ Em contrapartida, a parentalidade patogênica ${ }^{36}$ potencializa o comportamento ansioso, inseguro, superdependente e imaturo que pode levar o indivíduo, em condições de estresse, a desenvolver sintomas neuróticos, depressão ou fobia, mas, principalmente, violência. ${ }^{37}$

Nesse contexto, cabe indagar se haveria algum método eficiente para ajudar aos pais na formação da personalidade dos seus filhos. Por meio dos relatos

33 BOTTON, 2011.

34 BOWLBY, 2006, p. 139.

35 "Na literatura psicanalítica, diz-se que uma pessoa assim tem um ego forte; e pode ser descrita como alguém que é dotado de "confiança básica" Erikson, 1950; de "dependência Madura", Fairbairn, 1952; ou que "introjetou um objeto bom", Klein, 1948. Nos termos da teoria da ligação, a pessoa é descrita como tendo construído um modelo representacional de si mesma como sendo capaz de se ajudar e merecedora de ser ajudada se surgirem dificuldades" BOWLBY, 2006, p. 179.

36 Nos estudos de Bowlby, os indivíduos que desenvolvem tais sintomas "estiveram expostos a pelo menos um, e geralmente mais de um, de certos padrões de parentalidade patogênica, os quais incluem: a ausência persistente de respostas de um ou ambos os pais o comportamento eliciador de cuidados, da criança e/ou depreciação e rejeição marcada; b descontinuidade de parentalidade, ocorrendo mais ou menos frequentemente, incluindo períodos em hospital ou instituição; c ameaças persistentes por parte dos pais de não amar a criança, usadas como um meio para controlá-la; d ameaças, por parte dos pais, de abandonar a família, usadas ou como método de disciplinar a criança ou como uma forma de coagir o cônjuge; e ameaças por parte de um dos pais de abandonar ou mesmo matar o outro, ou então de cometer suicídio estas ameaças são mais comuns do que se poderia supor; a indução de culpa à criança, afirmando que o comportamento dela é ou será responsável pela morte de um dos pais. Qualquer dessas experiências pode levar uma criança, um adolescente ou um adulto a viverem em constante ansiedade, com medo de perder sua figura de ligação e, por conseguinte, a ter um baixo limiar para a manifestação do comportamento de ligação". 2006, p. 180.

37 BOWLBY, 2006, p. 180. No mesmo sentido, GILLIGAN, 2001. 
médicos, sabe-se mais o que deve ser evitado do que sobre métodos infalíveis e eficazes para a formação da personalidade dos filhos. Além disso, o modo como as intervenções são realizadas é mais importante do que a própria intervenção em si. ${ }^{38} \mathrm{O}$ afeto constitui o vínculo de proximidade duradouro, que se estabelece entre indivíduos específicos, capaz de lhes proporcionar envolvimento emocional, apoio e segurança. ${ }^{39}$ Por meio da base segura que a figura de ligação promove, a criança tende a empreender mais facilmente a sua jornada emancipatória. Neste sentido, educar o filho é apoiar seu desenvolvimento e promover o exercício de uma liberdade responsável, auxiliando no processo de formação de uma pessoa adulta, solidária e autônoma. ${ }^{40}$

A despeito das eventuais dificuldades pessoais de cada pai ou mãe, o Direito estabelece hoje direitos fundamentais de crianças e adolescentes que não podem ser lesados. A autoridade dos pais, entendida exclusivamente como um múnus privado, desapareceu, porque hoje se considera que ela transcende o interesse pessoal ou a mera vontade de obediência dos filhos. ${ }^{41}$ Há, portanto, atualmente, numerosas normas jurídicas constitucionais e infraconstitucionais que limitam o exercício da autoridade parental em prol dos interesses dos filhos.

\section{DIREITOS PERSONALÍSSIMOS DO MENOR: LIBERDADE E PRIVACIDADE}

No Brasil, o princípio do melhor interesse da criança alcançou fundamentalidade

38 Segundo Bowlby, 2006, p. 33-34: "(...) Aqueles que, na infância, experimentaram intensa ambivalência em relação a seus pais ou irmãos, e que recorreram então, inconscientemente, a um dos muitos mecanismos primitivos e precários de resolver o conflito (...) - repressão, deslocamento, projeção, etc. - estão despreparados para a renovação do conflito quando se tornarem pais. Em vez de reconhecerem a verdadeira natureza de seus sentimentos em relação à criança e de ajustarem seu comportamento, veem-se instigados e impelidos por forças que ignoram, e mostram-se perplexos por serem incapazes de agir com todo o amor e paciência que desejam."

39 O comportamento de ligação consiste em "qualquer forma de comportamento que resulta em que uma pessoa alcance ou mantenha a proximidade com algum outro indivíduo diferenciado e preferido, o qual é usualmente considerado mais forte e ou mais sábio. Embora seja especialmente evidente durante os primeiros anos da infância, sustenta-se que o comportamento de ligação caracteriza os seres humanos do berço à sepultura" (BOWLBY, 2006, p. 171).

40 IANNI, 1977, p. 875.

41 Um bom exemplo sobre a questão envolve a possibilidade de homeschooling e a resistência por parte do Estado brasileiro pautada, especialmente, no art. 55, do Estatuto da Criança e do Adolescente, que "os pais ou responsáveis têm obrigação de matricular seus filhos ou pupilos na rede regular de ensino". 
material com a sua inscrição no art. 227 da Constituição, impondo-se à família, à sociedade e ao Estado o dever de sua promoção. Pressuposto de uma sociedade solidária, esse princípio também é estabelecido pela Convenção sobre os Direitos da Criança e do Adolescente (art. 18) ${ }^{42}$, que igualmente reafirma a criança e o adolescente como destinatários dos direitos proclamados na Carta das Nações Unidas e nas declarações universais de direitos. ${ }^{43}$

Em lugar da conjugalidade é a parentalidade e a filiação a assumirem a centralidade institucional da família contemporânea. ${ }^{44}$ Enquanto a conjugalidade tem fundamento substancial nos princípios da igualdade e da liberdade, a relação paterno-filial articula-se por meio da solidariedade, a qual fundamenta o trinômio liberdade, igualdade e responsabilidade. Ainda que se respeitem os direitos dos filhos, o dever parental de cuidado poderá permitir intervenções legítimas na seara da liberdade e da privacidade dos menores.

Entre pais e filhos há uma relação assimétrica, na qual os filhos menores, dada a sua vulnerabilidade, recebem especial tutela e aos pais se atribui a responsabilidade por sua criação, educação e sustento (art. 227, CF). No exercício da autoridade parental, a liberdade dos pais desvanece em face da solidariedade

42 "Artigo 18: 1. Os Estados Partes envidarão os seus melhores esforços a fim de assegurar o reconhecimento do princípio de que ambos os pais têm obrigações comuns com relação à educação e ao desenvolvimento da criança. Caberá aos pais ou, quando for o caso, aos representantes legais, a responsabilidade primordial pela educação e pelo desenvolvimento da criança. Sua preocupação fundamental visará ao interesse maior da criança.

2. A fim de garantir e promover os direitos enunciados na presente convenção, os Estados Partes prestarão assistência adequada aos pais e aos representantes legais para o desempenho de suas funções no que tange à educação da criança e assegurarão a criação de instituições, instalações e serviços para o cuidado das crianças. 3. Os Estados Partes adotarão todas as medidas apropriadas a fim de que as crianças cujos pais trabalhem tenham direito a beneficiar-se dos serviços de assistência social e creches a que fazem jus." Convenção sobre os Direitos da Criança e do Adolescente. Disponível em: <http://www.planalto.gov. br/ccivil_03/decreto/1990-1994/D99710.htm.htm>. Acesso em: 15.05.2014.

43 A Declaração dos Direitos Humanos da Organização das Nações Unidas reconhece a vida privada como um direito do homem, no art. $12^{\circ}$. O art. $8^{\circ}$. da Convenção para a Proteção dos Direitos do Homem e das Liberdades Fundamentais também dispõe sobre a vida privada e a intimidade como direitos individuais. Além disso, o Pacto San José da Costa Rica, apesar de adotar uma redação mais pulverizada, garante a proteção da vida privada nos artigos 11.2, 11.3, 17 e 19. Pelo disposto no art.11.2 e 3, tem-se que "Ninguém pode ser objeto de ingerências arbitrárias ou abusivas em sua vida privada, em sua família, em seu domicílio ou em sua correspondência, nem de ofensas ilegais à sua honra ou reputação. 3. Toda pessoa tem direito à proteção da lei contra tais ingerências ou tais ofensas".

MORAES, 2010, p. 427. 
familiar, razão pela qual não se admite o abandono impune dos seus filhos. ${ }^{45}$

O conflito primordial está, pois, em compatibilizar a responsabilidade de cuidar e educar, cerceando necessariamente a liberdade da criança, com a função de emancipar pela promoção da autonomia individual. Com efeito, é preciso reconhecer aos filhos a capacidade de exercício das liberdades previstas constitucionalmente, quando gozarem do necessário discernimento. Isso implica a dissociação da capacidade de agir da capacidade jurídica da criança, no que toca ao exercício de sua autonomia para realizar escolhas, especialmente quanto às matérias de natureza não patrimonial, na medida de sua maturidade e do seu juízo crítico. ${ }^{46}$

Foi a própria Convenção Internacional dos Direitos da Criança, em 1989, a prever em seu art. 12 uma regra expressa - que ainda hoje temos dificuldade em aplicar, presos que estamos à interpretação restrita dos artigos $3^{\circ}$ e $4^{\circ}$ do Código Civil. $O$ art. 12.1 da Convenção dispõe que os "Estados Partes devem assegurar à criança que é capaz de formular seus próprios pontos de vista o direito de expressar suas opiniões livremente sobre todos os assuntos relacionados a ela, e tais opiniões devem ser consideradas, em função da idade e da maturidade da criança".

Com tal objetivo, se proporcionará à criança, em particular, a oportunidade de ser ouvida em todo processo judicial ou administrativo que e afete, quer diretamente quer por intermédio de um representante ou órgão apropriado, em conformidade com as regras processuais da legislação nacional. ${ }^{47}$

Como sustenta a melhor doutrina, a capacidade de agir em matéria existencial não pode ser aferida da mesma forma como se mensura a capacidade para a prática

45 Há tipos penais que se perpetram por ofensa ao dever de assistência familiar, conforme se verifica no Código Penal Brasileiro, art. 244 e segs.

46 "Já não se trata simplesmente de rever os limites etários da capacidade civil, da nupcialidade ou mesmo de reconhecimento da validade dos negócios jurídicos empreendidos por menores em tenra idade. Penetra-se mais fundo a problemática subjacente às determinações tópicas de aptidão etária para se compreender que o fenômeno do crescimento biológico e emocional, que é contemporâneo da vida, tem de encontrar resposta permanente no direito, que requer assim determinações matizadas e flexíveis para a material. Sente-se nas suas novas tendências que o regime jurídico das relações paterno-filiais procura exprimir o que SCHWARTZ chamou de "pedagogia da escolha", que é, em suas próprias palavras, uma pedagogia de contrato, vale dizer, da liberdade" VILLELA, 1980, p. 32.

47 Embora o ECA, em seu art. 141, garanta o acesso de toda criança ou adolescente à Defensoria Pública, ao Ministério Público e ao Poder Judiciário, por qualquer de seus órgãos e o parágrafo único deste artigo preveja a nomeação de curador especial ao menor, sempre que os interesses destes colidirem com os de seus pai ou responsável, seu exercício não é usual. 
de atos civis de natureza patrimonial. ${ }^{48}$ Não parece razoável atribuir-se a alguém a titularidade de uma situação existencial (rectius, de um direito fundamental) sem Ihe conceder a capacidade de exercício. O discernimento, aqui, será o pressuposto para jurisdicizar e validar a manifestação de vontade do menor. ${ }^{49}$

Com base em tal fundamentação pode-se afirmar o direito à privacidade da criança e do adolescente. ${ }^{50}$ A considerar o art. 16, da citada Convenção, "Nenhuma criança será objeto de interferências arbitrárias ou ilegais em sua vida particular, sua família, seu domicílio ou sua correspondência, nem de atentados ilegais a sua honra e a sua reputação". A lei deverá protegê-la contra interferências ou atentados de tal ordem.

Nem mesmo aos pais é franqueada a faculdade da interferência arbitrária ou ilegal na vida particular de seus filhos menores, haja vista a dramática ruptura com o antigo conceito de pátrio poder, no qual a autoridade parental possuía uma espécie de direito subjetivo sobre a pessoa do filho. Atualmente a autoridade parental é instrumental, funcionalizada para a promoção da personalidade dos filhos. Eventual interferência paterno-materna na esfera privada do filho há que ser motivada pelo especial dever de cuidar e de promover sua segurança e a sua personalidade. A função estabelecida pelo ordenamento jurídico para a autoridade parental somente merece tutela se e quando for exercida como um múnus, um complexo de direitos e deveres visando ao melhor interesse dos filhos, da sua emancipação como pessoa, na perspectiva de sua futura independência. ${ }^{51}$

Transparece, de modo especial, a ambivalência própria das relações familiares, pois na conjugação das tarefas de cuidar e de emancipar, ora se cerceia, ora se promove a liberdade. ${ }^{52}$

Segundo atenta doutrina, se de muitas formas a família limita o indivíduo e o sacrifica em sua pretensão de liberdade, mas, por outro lado e ao mesmo tempo, ao possibilitar sua realização pessoal pelos contatos mais profundos a que dá

48 RUSCELLO, 2000, p. 59.

49 TEIXEIRA, 2009, p. 150.

50 MENEZES, 2013.

51 TEPEDINO, 2004, p. 41.

52 VILLELA, 1980, p. 10. 
origem, a família também o liberta, isto é, promove-lhe a personalização por meio do outro, de modo verdadeiramente único. ${ }^{53}$

$\mathrm{Na}$ qualidade de comunidade intermediária entre o indivíduo e o Estado, voltada para a proteção e a promoção da pessoa, "a família contemporânea definharia se tivesse que se confrontar com os valores pessoais, a autonomia, a liberdade ou o interesse do indivíduo". ${ }^{54} \mathrm{O}$ delineamento jurídico da família democrática não admite a configuração autoritária, embora não afaste o dever de obediência dos filhos em relação aos pais e nem os serviços que devem ser prestados por eles na medida de sua condição. ${ }^{55}$ Assim, é possível aos pais, em nome do cuidado conjugado com a promoção do desenvolvimento, tomar parte na vida privada dos filhos, especialmente se estes estiverem correndo riscos. Mas essa participação somente será legítima se tiver fundamento na promoção do seu desenvolvimento, na garantia da sua integridade e no respeito à sua dignidade, em conformidade com a doutrina da proteção integral. ${ }^{56}$

\section{OS NOVOS SIGNIFICADOS DA PRIVACIDADE}

A Constituição brasileira trata de vida privada e da intimidade como elementos essenciais ao desenvolvimento da personalidade. Mas não é fácil estabelecer o que sejam essas situações subjetivas na sociedade da informação. Recorre-se à explicação de Stefano Rodotà (2008), para quem a ideia de privacidade está em franca expansão. Define o autor a privacidade ora como o direito de manter controle sobre as próprias informações, ora como àquele "conjunto de ações, comportamentos, opiniões, preferências, informações pessoais, sobre os quais o interessado pretende manter um controle exclusivo". ${ }^{57}$ Privacidade implica, por fim, a "tutela das escolhas de vida contra toda forma de controle público e de estigmatização social". É com esta amplitude que se compreende a proteção constitucional à vida privada e

53 VILLELA, 1980.

54 IANNI, 1977, p. 866.

55 AUTORINO, 2007, p. 187.

56 V. VENCELAU e ABÍLIO, 2012, p. 339-354, que examinam a temática da autoridade parental e a liberdade dos filhos, informando a possibilidade restritiva dessa liberdade para promover o cuidado.

57 RODOTÀ, 2008, p. 92. 
à intimidade, prevista na Constituição Federal ( $\left.\operatorname{art} .5^{\circ}, \mathrm{X}\right)$, especialmente se a sua leitura se faz sob a ótica da dignidade da pessoa humana.

A intimidade é um prolongamento da personalidade e um requisito essencial ao seu desenvolvimento. ${ }^{58} \mathrm{~A}$ vida privada, por seu turno, é um espaço para a autodeterminação indissociável à condição de pessoa. Portanto, o sujeito capaz de protagonizar a sua própria história deverá ter a sua intimidade e a vida privada preservadas, ainda quando estiver sujeito à influência do poder familiar. Relembrese de que os elementos essenciais a sua personalidade são inalienáveis e gozam de especial proteção jurídica. É certo que a medida do seu discernimento e da sua maturidade determina a extensão da liberdade e da privacidade que os filhos gozam em face dos pais.

O direito da criança e do adolescente à vida privada é assegurado não apenas pela Convenção sobre os Direitos da Criança, mas também pelo próprio Estatuto da Criança e do Adolescente ${ }^{59}$, que ratifica para os seus destinatários todos os direitos deferidos à pessoa humana, inclusive a vida privada familiar e a vida privada individual. Entre os artigos 15 e 18, dispõe o ECA sobre a proteção da dignidade, o respeito e a liberdade da criança e do adolescente.

No campo das situações existenciais, é de notar que o menor já é sujeito de direitos que não podem ser negados pelo exercício do poder familiar: a vida, o nome, a honra, a imagem, a intimidade, as inclinações e as aspirações pessoais. Destaca-se, no tocante à privacidade, a necessidade de proteção dos seus dados sensíveis, tais como a sua convicção religiosa, filosófica, ideológica, a opinião política, o estado de saúde e a vida sexual, etc.

Assim, também os pais devem respeitar as disposições do Estatuto que garantem aos menores o direito de brincar, de se divertir, de escolher o esporte que pretendem praticar, sua liberdade de crença e culto e a sua liberdade de expressão (art.16). Se essa liberdade é mitigada pelo dever de obediência dos

58 CIFUENTES, 1995, p. 543.

59 Estatuto da Criança e do Adolescente, "Art. $3^{\circ} \mathrm{A}$ criança e o adolescente gozam de todos os direitos fundamentais inerentes à pessoa humana, sem prejuízo da proteção integral de que trata esta Lei, assegurando-se Ihes, por lei ou por outros meios, todas as oportunidades e facilidades, a fim de Ihes facultar o desenvolvimento físico, mental, moral, espiritual e social, em condições de liberdade e de dignidade". 
filhos aos pais, a quem cabe exercer o cuidado, na medida em que a criança e o adolescente alcançar discernimento, estes pais não poderão, de um modo genérico, impor-lhes certas escolhas: devem respeitar a sua autodeterminação quando demonstrarem capacidade decisional. ${ }^{60} \mathrm{~A}$ sujeição do menor à autoridade paterna egoísta e desarrazoada, no trato dessas questões não patrimoniais, pode implicar violação ao princípio da dignidade, da solidariedade e prejudicar, antes de promover, o desenvolvimento da personalidade. ${ }^{61}$

Mas, como referido, a principal dificuldade está na aferição do discernimento ${ }^{62}$ do menor. Para avaliar sua maturidade e seu nível de discernimento importa ouvilo, por meio de um diálogo aberto, no qual ele possa ser um interlocutor ativo. Na mesma medida em que seu discernimento aumentar o poder do genitor ${ }^{63} \mathrm{em}$ realizar as escolhas em nome do menor, deve retrair-se. A autoridade parental deve ser mais firme nos primeiros anos e mais flexível à medida que o menor vai alcançando a maturidade, momento em que se intensifica a promoção de sua autonomia. ${ }^{64}$ No primeiro momento, amplia-se o poder para melhor cuidar; na adolescência, promove-se o diálogo para a construção de soluções compartilhadas, visando mais o emancipar do que o cercear, embora persista o dever dos pais de zelar pela integridade psicofísica dos seus filhos adolescentes.

Dito isto e, citando questões práticas, como o exemplo no qual a criança ou o adolescente tenha interesse pelos entretenimentos oferecidos por meio da internet, poderão os pais disciplinar o uso do computador, estabelecendo os horários para o acesso, o local em que o equipamento deve ser instalado e o filtro para certos sítios eletrônicos, com a explicação devida, se solicitada. O acesso aos e-mails pessoais dos filhos, porém, poderá se assemelhar à violação

60 Com o novo tônus que a família assume, torna-se indispensável que "a relação parental seja examinada em seu perfil dinâmico, no âmbito do processo educacional de modo a que os filhos possam, aos poucos, libertar-se da vulnerabilidade inerente ao natural déficit de maturidade que Ihes é característico, decrescendo-se, progressivamente, em consequência, o grau de intervenção dos pais sobre seu discernimento e sua vontade, supridos, em intensidade variada, durante a incapacidade" TEPEDINO, 2009, p.203.

61 RUSCELLO, 2000, p. 69.

62 Para Maria Celina Bodin de Moraes, "discernimento, ou capacidade de compreensão e análise, provém de uma característica da condição humana, se não a mais importante a que melhor define a nossa espécie: a racionalidade" (MORAES, 2010, p. 192).

63 AUTORINO, 2007, p. 186.

64 IDEM, ibidem. 
de correspondências pessoais. Ressalve-se, porém, que o cuidado com as crianças menores deve ser maior. Os pais podem, mediante prévio diálogo, acompanhar as mensagens achadas nas contas eletrônicas de seus filhos de menor idade, mais imaturos e mais suscetíveis aos abusos de terceiros. Por óbvio, não podem fazer uso dessas informações para atingir ou expor a personalidade dos filhos. A motivação deve ser legítima e adequada ao fim precípuo do poder familiar, qual seja: a proteção e a promoção da pessoa em desenvolvimento.

No tocante à participação da criança em redes sociais, cabe ressaltar que os cuidados e a supervisão são essenciais nos primeiros anos e secundários ao longo do amadurecimento do filho. Enquanto eventual intromissão no e-mail pessoal da criança, para evitar assédio de adultos mal intencionados, é uma atitude recomendável, a mesma intervenção em relação aos filhos adolescentes, para controlar os relacionamentos afetivos próprios da idade pode não ser razoável. É comum, nos dias atuais, que o adolescente use as mensagens eletrônicas como forma de comunicação, e a sua intimidade nesta seara deve ser respeitada. ${ }^{65}$ Contudo, não se poderá tratar como uma intrusão desarrazoada aquela conduta invasiva do pai ou da mãe que tem a forte suspeita do envolvimento do filho adolescente com drogas ou demais ilícitos. Ainda nesta fase da vida do filho remanescem o dever de cuidado e a responsabilidade perante terceiros dos pais.

Conflito sério ocorreu nos Estados Unidos em 2010 quando um adolescente decidiu processar a própria mãe pelo fato desta ter acessado sua conta numa rede social, quando ele a esqueceu aberta no computador da casa materna. ${ }^{66} \mathrm{O}$ menor morava com a avó e estava em visita à mãe, acometida por problemas de saúde. Além de ler as mensagens, a mãe postou diversos comentários negativos em nome do rapaz e mudou a senha para que ele não pudesse acessar novamente

65 Parte da doutrina admite que o dano decorrente da violação da intimidade pelos pais é suscetível de reparação. Assim, entre outros, Valeria Corriero a qual afirma: "In questa prospettiva si è giunti a sostenere che il comportamento di un genitore che violi il diritto alla riservatezza del minore possa non soltanto comportare un provvedimento di limitazione o decadenza dalla potestà genitoriale ex art. 330 ss. cc. nei casi più gravi, ma anche una tutela risarcitoria per i danni subiti dal figlio". (CORRIERO, 2000, p. 999-1000).

66 "Mother Denise New Convicted Of Harassment For Hijacking Son's Facebook Page". Disponível em: http://www.huffingtonpost.com/2010/05/27/mother-denise-new-convict_n_592850. html. Acesso em: 10.10.2014. 
o site. Ao tomar conhecimento do fato, o filho intentou a ação, demandando que a mãe não pudesse mais se aproximar dele em razão do assédio que sua conduta intrusiva Ihe causara; julgada a ação, foi ela condenada a pagar multa e a manter distância do filho. ${ }^{67}$

\section{QUESTÕES DIFÍCEIS SOBRE A LIBERDADE DO MENOR}

Situações existenciais pertinentes ao corpo, aos dados genéticos e à recusa de tratamento médico tampouco podem ser tratadas apenas pelos pais, no esquema da substituição da vontade do menor. Ainda que se lhes atribua o dever de zelar pela saúde e integridade psicofísica dos filhos, é importante considerar o interesse e a vontade dos principais envolvidos. A esse respeito, a Declaração Internacional sobre Dados Genéticos Humanos, de 16 de outubro de 2003, destaca a necessidade de se considerar o consentimento do menor, na conformidade com o seu discernimento e maturidade. Em todo caso, destaca a importância de os representantes legais considerarem o seu interesse fundamental. Nos termos do art. 8, alínea c,: "(...) A opinião de um menor deverá ser tomada em consideração como um fator cujo caráter determinante aumenta com a idade e o grau de maturidade". Cumpre sempre, evidentemente, distinguir entre a pequena criança e o adolescente que já possui um grau elevado de desenvolvimento moral e intelectual.

Na realidade, o Código Civil impede os atos de disposição do próprio corpo a todas as pessoas, quando importarem em diminuição permanente, exceto se houver exigência médica (art. 13). E ainda quando houver essa exigência, é de se indagar sobre a importância do consentimento do menor interessado. ${ }^{68}$

Segundo David Le Breton, para muitos contemporâneos, o corpo é uma matéria-prima a modelar, uma representação provisória da identidade, um lugar

67 A mãe foi condenada a 30 dias de prisão, pena suspensa em troca do pagamento de uma multa de cerca de $\mathrm{R} \$ 1.200,00$ e a participação em cursos sobre o bom exercício da parentalidade e sobre o controle das próprias emoções. O juiz determinou ainda que se a condenada concluísse os cursos em um ano, poderia receber permissão para novamente ver seu filho.

68 O Conselho Regional de Medicina, seccional Ceará, emitiu um parecer sobre essa questão, reconhecendo a autonomia de uma jovem de dezessete anos, portadora de sarcoma de fêmur esquerdo, para recusar a intervenção médica eletiva de amputação do membro inferior, contrapondo-se à orientação do médico e ao posicionamento dos pais. Parecer CREMEC n. 5746/05, de 26.12.2005. Relatores Dalgimar Bezerra de Menezes e Urico Gadelha de Oliveira Neto. 
de encenação de efeitos especiais. ${ }^{69} \mathrm{O}$ desejo por essa maleabilidade corporal atinge adultos e adolescentes que almejam cirurgias plásticas, liftings, implantes subcutâneos para indução de proporções físicas desejadas, piercings, tatuagens e até mesmo modificações corporais mais severas. ${ }^{70}$ Não se pode afastar a autoridade parental de decisões como estas, afinal cabe aos pais o zelo e o cuidado para com a pessoa dos filhos. ${ }^{71}$

A Lei dos Transplantes (Lei $n^{\circ}$ 9.434/97, art. 9) estabelece que somente a pessoa juridicamente capaz pode dispor gratuitamente de tecidos, órgãos e partes do próprio corpo vivo. O menor, portanto, não poderá fazer doação de órgãos, apenas de medula óssea. Para que essa doação seja possível, exige-se que o procedimento não acarrete riscos à sua saúde, bem como a comprovada compatibilidade imunológica, o consentimento de ambos os pais ou de seus representantes legais e a autorização judicial. Mesmo nesta hipótese, é de se perguntar sobre a importância que se atribui à vontade do menor, se houver conflito de interesses entre ele e seus pais ou responsáveis. Quando a vontade conjunta dos pais for pela doação da medula e o menor não comungar o mesmo interesse, terá a oportunidade de ser ouvido pelo Ministério Público e pelo juiz? O ECA lhe dá tal garantia. E, do mesmo modo, o menor com maturidade e discernimento para manifestar o interesse em doar medula óssea a um meioirmão, se não puder fazê-lo por falta de concordância dos pais, poderá pleitear o suprimento judicial.

As questões atinentes à sexualidade também se inserem no processo educativo e podem atrair conflitos entre os direitos dos filhos e a manifestação da autoridade parental. A descoberta do corpo, a compreensão da pessoa do outro, as perguntas sobre a reprodução; a identidade de gênero; o marco da vida sexual ativa; a prevenção contra as doenças sexualmente transmissíveis e a gravidez precoce; a proteção contra o abuso, contra a violência e a exploração sexual são questões

69 LE BRETON, 2003, p. 29.

70 Alguns Estados brasileiros, a exemplo de São Paulo e do Rio de Janeiro, proíbem expressamente que se façam tatuagens ou implantem piercings em pessoas menores de idade, sem a autorização dos pais ou responsáveis. Decisão recente da 9a Câmara de Direito Criminal do Tribunal de Justiça de São Paulo entendeu que a realização de tatuagem em menor de idade constitui lesão corporal de natureza gravíssima.

71 Stanzione e Sciancalepore, 2006. 
atinentes à sexualidade e importantes na formação da criança e do adolescente. Desde cedo, os pais são chamados a lidar com a temática, orientando seus filhos. Conjugam nesta tarefa os deveres de cuidar, proteger e educar com o respeito à intimidade e à dignidade da pessoa. ${ }^{72}$

Em termos gerais, o foco da proteção jurídica é contra o abuso, a violência e a exploração sexual de crianças e adolescentes por membros da família ou por terceiros. Nesta mesma direção, tem-se as normas da Convenção sobre os Direitos da Criança $^{73}$ (art.34), o próprio Estatuto da Criança e do Adolescente (art.101, §2 e art. 244) e a lei $n^{\circ}$ 2.015/2009, que acrescentou o art. 217-A ao Código Penal, tipificando como estupro de vulnerável a relação sexual com menor de 14 anos, ainda que consentida. ${ }^{74}$

Aplicando o critério etário, o legislador penal presumiu que o menor de 14 anos é uma pessoa em formação, sem o necessário entendimento para decidir livremente sobre o início de sua vida sexual ativa.

Por outro lado, a legislação civil estabelece que os homens e as mulheres atingem a idade nupcial aos dezesseis anos (art.1517, CC), presumindo, mais uma vez pelo critério etário, que a partir dessa idade o adolescente alcançou a maturidade sexual, intelectual e psíquica indispensáveis ao casamento. ${ }^{75}$

De acordo com os dados da organização não governamental Bem-Estar Familiar

72 Segundo o art. 18 do ECA, "é dever de todos velar pela dignidade da criança e do adolescente, pondo-os a salvo de qualquer tratamento desumano, violento, aterrorizante, vexatório ou constrangedor".

73 Ratificada pelo Brasil por meio do Decreto no 99.710, de 21 de novembro de 1990.

74 A jurisprudência dos tribunais superiores tem reafirmado a presunção absoluta da violência. Contudo, em voto vencido no HC 97.052, o Ministro Marco Aurélio contrapôs-se à aplicação do caráter absoluto da presunção de violência na hipótese. Em sua justificativa, afirmou que muitos menores já têm relações sexuais antes dos quatorze anos por livre decisão. Na sua perspectiva, seria fundamental observarem-se os detalhes de cada caso, especialmente o depoimento da vítima, pois os costumes mudaram e é possível existirem jovens menores de quatorze anos, com aparência de mais idade e com vida sexual desenvolvida, que consintam livremente com uma relação mais íntima sem que, para isso, sejam constrangidas. Assim, a presunção absoluta de violência deveria ceder às peculiaridades de cada caso. Disponível em: <http:// redir.stf.jus.br/paginadorpub/paginador. jsp?docTP=AC\&docID=627298>. Acesso em: 15.05.2014.

75 É bem verdade que o mesmo artigo exige a autorização dos pais para que o casamento seja celebrado. Não obstante, o juiz poderá suprir essa autorização se os pais a negarem injustamente (art. 1.519, CC), mostrando que a vontade deliberada dos pais não obstará o matrimônio, exceto se fundamentada em justo motivo. Independentemente da idade nupcial, o juiz poderá autorizar o casamento de menor no caso de gravidez (art.1.520, CC). 
(BEMFAM, 2011) e do UNICEF (2012), nos anos de 2011/2012, cerca de trinta e três por cento dos adolescentes brasileiros, na faixa etária entre 12 e 17 anos, já haviam tido relações sexuais. ${ }^{76} \mathrm{~A}$ despeito da dependência econômica dos pais, os adolescentes vêm iniciando a sua vida sexual mais cedo, muitas vezes, de forma espontânea e pouco zelosa, haja vista os diagnósticos de doenças sexualmente transmissíveis e de gravidezes não planejadas nesta mesma fase. ${ }^{77}$ Em decorrência desse quadro, políticas públicas permitem a distribuição de contraceptivos aos menores relativamente incapazes, independentemente de seu estado civil ou da autorização dos responsáveis.

Outro tema delicado, pertinente à vida privada do menor, refere-se à liberdade de crença e culto. A partir de que idade a pessoa pode escolher sua própria religião, manifestar uma fé e escolher um tipo de culto ${ }^{78}$ Os pais podem tentar persuadir, orientar e convencer, mas, evidentemente, não podem usar de violência física ou psíquica para constranger o filho à fé. Compreendendo a subjetividade da fé, do direito à crença, talvez os pais não tenham tanta ingerência. Seguir os pais à igreja, de modo automático, não significa professar a mesma fé. O delineamento jurídico do poder familiar permite aos pais orientar o filho conforme o código de regras religiosas e morais que professarem. Mas a educação das crianças de acordo com uma determinada crença também encontra limite no melhor interesse da criança. A adesão a uma fé religiosa e o desempenho de suas práticas não

76 BRASIL. Cadernos temáticos: Direitos sexuais são direitos humanos. Secretaria Especial de Direitos Humanos. Subsecretaria de Promoção dos Direitos da Criança e do Adolescente. Brasília: DF, 2008. Disponível em: <http://www.comitenacional.org.br/files/biblioteca/ M4JMLPCPFMKFK5HL8Z5R.pdf>. Acesso em: 20.10.2014.

77 "Mesmo com a crescente difusão de informações sobre sexualidade, a interiorização das normas contraceptivas entre nós é frágil. A manutenção de uma prática espontaneísta e pouco reflexiva da sexualidade entre os jovens - característica da cultura sexual brasileira - reforça os estereótipos de gênero e dificulta a adoção de medidas preventivas à gravidez e às DST/AIDS." (ALVES; BRANDÃO, 2009, p. 661).

78 Sendo o Brasil um país eminentemente cristão, a despeito das muitas religiões que já se praticam no cenário nacional, observe-se o ensinamento bíblico como um exemplo. No livro de Provérbios, capítulo 22, vs. 6, diz-se "Ensina a criança no caminho que deve andar, e, ainda quando for velho não se desviará dele". Do trecho extrai-se que os pais devem apresentar os ensinamentos bíblicos aos filhos a partir de sua própria conduta no caminho e não apenas por palavras ou pelo currículo do catecismo e das escolas dominicais. A conduta dos pais é muito mais impactante como exemplo do que a sua fala. Do mesmo modo, conforme ensina o Novo Testamento, a salvação em Cristo é algo pessoal e não uma imposição familiar, o que não desautoriza, registre-se, a orientação familiar. A pessoa deve confessar aquela fé, por si, e não por imposição do pai ou da mãe. 
poderão ocasionar prejuízo à prole..$^{79}$

Contudo, em razão de ser a crença uma questão existencial, à medida que o filho reunir condições de realizar uma escolha consciente, os pais deverão respeitar a sua orientação, ainda que remanesça o dever de cuidado e de proteção. Quando a confissão de uma crença for acompanhada de uma conduta coerente e equilibrada, por que poderiam os pais intervir proibitivamente? É de ressaltar a sutil distinção entre crença e culto que integram a chamada liberdade religiosa, direito assegurado pelo ECA, no art.16, III. A primeira, diz respeito à experiência subjetiva da fé, enquanto a segunda, liberdade de culto, envolve a participação nas cerimônias e nas celebrações coletivas de uma dada religião. Se a autoridade parental não tem tanta ingerência no que toca à fé, poderá intervir no exercício da liberdade de culto, quando esta expuser a saúde, a segurança e a personalidade do filho ao risco. ${ }^{80}$ Não é incomum entre nós o conflito que se estabelece entre os hospitais e os pais que professam o credo Testemunha de Jeová, quando os seus filhos menores vêm a necessitar de transfusão de sangue. ${ }^{81}$

Destaca-se que a laicidade não resulta na total indiferença do Estado à religião, mas na garantia da liberdade religiosa em um regime de pluralismo confessional e cultural que beneficia a todos, inclusive o menor. ${ }^{82}$ Não é demais lembrar que a Convenção sobre os Direitos da Criança prevê, expressamente, que os Estados deverão assegurar-Ihes a liberdade de pensamento, de consciência e de religião (art.14).

79 STANZIONE e SCIANCALEPORE, 2006, p.130. A esse respeito, Stanzione e Sciancalepore (2006) citam decisão do Tribunal de Roma, na qual se determina a retirada do menor da residência familiar para se Ihe prestar tratamento médico adequado. Os pais recusavam a intervenção médica, por razões de ordem religiosa.

80 A esse respeito vale mencionar a decisão do Tribunal do Rio Grande do Sul que, em sede de Agravo de Instrumento, reverteu a guarda do menor de seis anos em favor do pai, após a comprovação de que a mãe, sem prévio consentimento do outro genitor, conduzia o menor para as cerimônias da entidade conhecida como Santo Daime, permitindo a sua participação em todos os rituais, dentre os quais a ingestão do chá de ayahuasca: v. TJRS, Proc. no 70037756525. Rel. Des. Alzir Felippe Schmitz, julg. em 16.12.2010.

81 No final do ano de 2013, um recém-nascido, filho de uma menor de 15 anos, morreu no setor de Neonatal do Hospital Geral de Fortaleza (HGF) após a avó recusar que fosse realizada a transfusão de sangue que poderia salvar a vida da criança, alegando razões religiosas. Disponível em: <http://diariodonordeste.verdesmares.com.br/cadernos/cidade/ online/recem-nascido-morre-no-hgf-apos-avo-recusar-transfusao-de-sangue-1.855760> . Acesso em: 16.06.2014.

82 STANZIONE e SCIANCALEPORE, 2006, p. 135. 
Em linhas gerais, repita-se, a eventual tensão entre poder familiar e o respeito à vida privada dos filhos terá de ser mediada pela composição entre o dever de cuidado e a promoção da emancipação, sempre respeitando os princípios da dignidade da pessoa, da liberdade, da igualdade e do melhor interesse da criança.

\section{CONSIDERAÇÕES FINAIS}

Descortinada a importância da infância e da adolescência ao longo do século $X X$, emergiram os já mencionados documentos internacionais sobre direitos humanos, especialmente voltados para a pessoa nessa fase do desenvolvimento. A plataforma protetiva ali estabelecida findou por delinear limites ao poder familiar. Instituiu-se a doutrina da proteção integral, por meio da qual a invisibilidade social do menor cedeu lugar ao princípio do melhor interesse da criança, elemento norteador das decisões que lhes dizem respeito. Os pais, os responsáveis, as instituições, as autoridades, os tribunais ou quaisquer entidades deverão sempre optar pela escolha que lhes proporcionar o máximo bem-estar possível. Nesse processo, a criança ou o adolescente emerge como um sujeito ativo, titular do direito de manifestar suas razões, crenças e pensamentos.

Como o melhor interesse da criança não é uma espécie normativa de conteúdo predeterminado, mas um princípio aberto que orienta a opção pela alternativa mais adequada à dignidade da pessoa menor, quando houver conflito envolvendo seus interesses, sua aplicação não se afigura tarefa fácil. Desafiará o aplicador do direito a abandonar sua percepção individual do que seja certo ou errado para considerar as influências dos fatores psicossociais circundantes a cada caso, cabendo-Ihe recorrer aos conhecimentos de outras áreas das ciências humanas e ao parecer de profissionais dessas áreas, tais como médicos, psicólogos, psicanalistas, terapeutas e pedagogos.

A família democrática impõe uma relação coordenada entre pais e filhos, a assimetria existente entre ambos os polos seja mediada pelo perfil funcional 
que tem o poder familiar de promoção da pessoa do vulnerável. Cabe à autoridade parental acompanhar o menor no paulatino processo de construção da personalidade, reconhecendo-lhes as possibilidades de protagonizar sua própria história. Como indivíduos em formação, sua personalidade ainda está em desenvolvimento e seu direito geral de liberdade não é pleno. Gozam de uma liberdade assistida, eventualmente vigiada, que vai se expandindo na proporção do seu amadurecimento. A permissão exagerada, embora seja apreciada pela população infanto-juvenil, não representará, frequentemente, a solução mais adequada. ${ }^{83}$ Por vezes, é a limitação saudável e motivada que promoverá o melhor interesse do adolescente ou da criança. ${ }^{84}$

Infelizmente, porém, ainda se assiste a uma realidade contraditória, o cotidiano denuncia a discrepância entre o modelo democrático de família e a organização de muitos grupos familiares que se acham na realidade. Os jornais, as ruas e os tribunais ainda apresentam famílias adoecidas pela falta do respeito mútuo, de zelo ou pior, pelo abandono ou pela violência contra as crianças, mulheres e idosos. Não raro, os filhos adolescentes crescem sem reconhecer a legitimidade da autoridade parental e são refratários a ideia de respeitar e obedecer a seus pais. Talvez a crise que se ostenta não esteja na modificação do instituto do pátrio poder para o poder familiar, mas na inabilidade dos pais de construíremse como referência de apoio e autoridade legítima.

Por meio de uma sólida relação paterno-filial, na qual a ligação afetiva foi construída a cada dia, na vivência de experiências boas e no enfrentamento dos momentos ruins, os conflitos virão, mas serão ultrapassados pela intervenção amistosa ou pelo diálogo respeitoso. É necessário reconhecer a força política do modelo da família democrática, ainda que seja como um futuro a perseguir. ${ }^{85}$ Mais

83 TEIXEIRA, 2009, p. 215.

84 A criança "quer" o limite, dizem os psicólogos e os psicanalistas infantis porque essa é a maneira que têm de garantir a atenção dos pais ou responsáveis.

85 Nas linhas de Commaille, 1998, p. 22: "The family imagery as a space of Love for one's fellow man, unlimited generosity, solidarity, affective and material reciprocity, a meeting of souls, in other words as a space that has a potential for universality and sublimation of differences, thus serves to construct an image of politics that is always present, at least in the form of nostalgia: that of a bygone past, or a utopia, a future to attain". Em tradução livre: A imagem da família como um espaço de amor ao próximo, de generosidade ilimitada, solidariedade, reciprocidade afetiva e material, um encontro de almas, em outras palavras, como um espaço que tem um potencial de universalidade e sublimação das diferenças, ser- 
que isso, os instrumentos jurídicos que a delineiam já estão postos, havendo como exigi-los. Não se pode apregoar a importância da democracia no espaço público e estranhar a sua utilização para os grupos privados, como são as comunidades intermediárias.

\section{REFERÊNCIAS}

ALVES, Camila Aloísio e BRANDÃO, Elaine Reis. Vulnerabilidades no uso de métodos contraceptivos entre adolescentes e jovens: interseções entre políticas públicas e a atenção à saúde. Ciência e saúde coletiva [online]. Vol. 14, n. 2. 2009.

AUTORINO, Gabriella. Situazioni esistenziali dei figli minori e potestà dei genitori.In: AUTORINO, Gabriella; STANZIONE, Pasquale. Diritto civile e situazioni esistenziali. Torino: Giappichelli, 2007, p. 178-195.

BARBOZA, Heloisa Helena. Biodireito x Bioética: insuficiência dos conceitos jurídicos. In: BARRETO, Vicente de Paulo (Org.); BARBOZA, Heloisa Helena (Org.). Temas de biodireito e bioética. Rio de Janeiro: Renovar, 2001.

BRASIL. Cadernos temáticos: Direitos sexuais são direitos humanos. Secretaria Especial de Direitos Humanos. Subsecretaria de Promoção dos Direitos da Criança e do Adolescente. Org. Neide CASTANHA. Brasília: Distrito Federal, 2008. Disponível em http://www.comitenacional. org.br/files/biblioteca/ M4JMLPCPFMKFK5HL8Z5R.pdf>. Acesso em: 20.10.2014.

. Conselho Regional de Medicina do Estado do Ceará. O direito do paciente de recusar tratamento. Parecer CREMEC n. 5746/2005, de 26.12.2005. Relatores Dalgimar Bezerra de Menezes e Urico Gadelha de Oliveira Neto.

BOWLBY, John. Formação e rompimento dos laços afetivos. São Paulo: Martins Fontes, 2006.

BOTTON, Alain de. A lógica de ser pai e mãe em tempos modernos. BBC Brasil Notícias, atualizado em 10 de agosto de 2011. Disponível em: <http://www.bbc.co.uk/portuguese/ noticias/2011/08/110809_crianca_allan_boton_mdb.shtml>. Acesso em: 30.10.2013.

CARBONERA, Silvana Maria. Reserva de intimidade: Uma possível tutela da dignidade no espaço relacional da conjugalidade. Rio de Janeiro: Renovar, 2008. 
CIFUENTES, Santos. Derechos personalísimos. Buenos Aires: Astrea, 1995.

COMMAILLE, Jacques. Family and Democracy. In: MATTHIJS, Koen (Ed.). The Family: Contemporary Perspectives and Challenges. Festschrift in Honor of Wilfried Dumon. Leuven/Louvain: Leuven University Press, 1998, p. 19-30.

CORRIERO, Valeria. Privacy del minore e potestà dei genitori. Rassegna di diritto civile, 2000, p. $999-1000$.

COSTA JUNIOR, Paulo José da. O direito de estar só. Tutela penal da intimidade. São Paulo: Rio de Janeiro, 2007.

DONEDA, Danilo. Da privacidade à proteção dos dados pessoais. Rio de Janeiro: Renovar, 2006.

GIDDENS, Anthony. A terceira via: reflexões sobre o impasse político atual e o futuro da social-democracia. Rio de Janeiro: Record, 1999.

A transformação da intimidade. Sexualidade, amor e erotismo nas sociedades modernas. São Paulo: Unesp, 1993.

GILLIGAN, James. Preventing Violence (Prospects for Tomorrow). London: Thames \& Hudson, 2001.

GILISSEN, John. Introdução histórica ao direito. 2. ed., Lisboa: Calouste Gulbenkian, 1995.

IANNI, Paolo. Potestà dei genitori e libertà dei figli. In: LOJACONO, V. (Dir.), Il diritto di famiglia e delle persone. Milano: Giuffrè, 1977, p. 875.

JUNG, Carl G. O desenvolvimento da personalidade. São Paulo: Vozes, 2011.

LE BRETON, David. Adeus corpo. Antropologia e sociedade. Campinas: Papirus, 2003.

LEWICKI, Bruno C. Poder parental e liberdade do menor. Direito, Estado e Sociedade, Rio de Janeiro: PUC-Rio, v. 9, n. 17, p. 6-30, ago./dez. 2000.

MARTINS, Rosa. Responsabilidades parentais no século XXI: a tensão entre o direito de participação das crianças e a função educativa dos pais. In: OLIVEIRA, G.; SILVA PEREIRA, T. Cuidado e vulnerabilidade. São Paulo: Atlas, 2009, p. 76-95.

MENEZES, Joyceane Bezerra de. A família e o direito de personalidade: a cláusula geral de tutela na promoção da autonomia e da vida privada. In: MENEZES, Joyceane B. e MATOS, Ana Carla H. (Org.). Direito das famílias por juristas brasileiras. São Paulo: Saraiva, 1993, p. 91- 
130.

MORAES, Maria Celina Bodin de. Na medida da pessoa humana. Estudos de direito civilconstitucional. Rio de Janeiro: Renovar, 2010.

. A nova família, de novo - Estruturas e função das famílias contemporâneas. Pensar, Revista de Ciências Jurídicas, v. 18, n. 2, p. 587-628, mai./ago. 2013.

. Do outro lado da rua. civilistica.com. Revista eletrônica de Direito Civil, a. 1, n. 2, 2012. Disponível em: http://civilistica.com/do-outro-lado-da-rua/. Acesso em 18.10.2014.

. Uma ideia louvável contra a violência doméstica. civilistica.com. Revista eletrônica de Direito Civil, a. 2, n. 4, 2013. Disponível em: http://civilistica.com/uma-ideia-louvavel-contraa-violencia-domestica. Acesso em 30.09.2014.

PERLINGIERI, Pietro. La personalità umana nell'ordinamento giuridico. Camerino-Napoli: Jovene, 1972.

O direito civil na legalidade constitucional. Rio de Janeiro: Renovar, 2008.

RODRIGUEZ, Javier Llobet. La prohibición del castigo físico o humillante en el ámbito familiar. In: LLOVERAS, Nora y HERRERA, Marisa (Directoras). SANTOS, Diego B. y PICADO, Ana María (Coordinadores). El derecho de familia en Latinoamérica. Los derechos humanos en las relaciones familiares. Córdoba: Nuevo Enfoque Jurídico, 2010, p. 507-524.

PROST, Antoine. Fronteiras e espaços do privado. História da vida privada: da Primeira Guerra a nossos dias. São Paulo: Companhia das Letras, 1992, p. 13-154.

ROBL FILHO, Ilton Norberto. Direito, intimidade e vida privada. Paradoxos jurídicos e sociais na sociedade pós-moralista e hipermoderna. Curitiba: Juruá, 2010.

RODOTÀ, Stefano. A vida na sociedade da vigilância. A privacidade hoje. Org. Maria Celina Bodin de Moraes. Tradução de Danilo Doneda e Luciana Cabral Doneda. Rio de Janeiro: Renovar, 2008, p. 92.

ROUDINESCO, Elisabeth. A família em desordem. Rio de Janeiro: Jorge Zahar Editor, 2003.

RUSCELLO, Francesco. Potestà genitoria e capacità dei figli minori: dalla soggezione all'autonomia. Esperienze giuridiche. Vita Notarile Edizioni Giuridiche, 2000, p. 59.

SINGLY, François de. Le soi, le couple e la famille. Paris: Nathan, 1996.

A reinvenção da família. Label France. n. 39, abril de 2000, p. 3. 
STANCIOLI, Brunelo. Sobre a capacidade de fato da criança e do adolescente: sua gênese e desenvolvimento na família. Revista Brasileira de Direito de Família. v. 1, n. 2, 1999, p. 2752.

STANZIONE, Pasquale e SCIANCALEPORE, Giovanni. Minori e diritti fondamentali. Milano: Giuffrè, 2006.

TEIXEIRA, Ana Carolina Brochado. Família, guarda e autoridade parental. Rio de Janeiro: Renovar, 2009.

TEPEDINO, Gustavo. A disciplina da guarda e a autoridade parental na ordem civilconstitucional. Revista Trimestral de Direito Civil. vol. 17, ano 5, p. 41, jan./mar. 2004.

. Tutela constitucional da criança e do adolescente. In: Temas de direito civil. Tomo III. Rio de Janeiro: Renovar, 2009, p. 201-226.

TUPINAMBÁ, Roberta. O cuidado como princípio jurídico nas relações familiares. In: 0 cuidado como valor jurídico. Rio de Janeiro: Forense, 2008, p. 123-151.

VENCELAU, Rose Melo; ABÍLIO, Viviane da Silveira. Autoridade parental como relação pedagógica: entre o direito à liberdade dos filhos e o dever de cuidado dos pais. In: Diálogos sobre o direito civil. TEPEDINO, Gustavo e FACHIN, Luiz Edson. Vol. III. Rio de Janeiro: Renovar, 2012, p. 339-354.

VILLELA, João Baptista. Liberdade e família. Série Monografias. Movimento Editorial da Revista da Faculdade de Direito da UFMG, vol. 1., n. 2. Belo Horizonte: Edição da Faculdade de Direito da UFMG, 1980.

WAISELFISZ, Julio J. Mapa da violência no Brasil. CEBELA - Centro Brasileiro de Estudos Latino-Americanos. FLACSO, 2012. Disponível em: <http://www.mapadaviolencia.org.br/ pdf2012/MapaViolencia2012_Criancas_e_Adolescentes.pdf>. Acesso em: 20.10.2014.

Recebido em: nov/2014

Aprovado em: mar/2015 